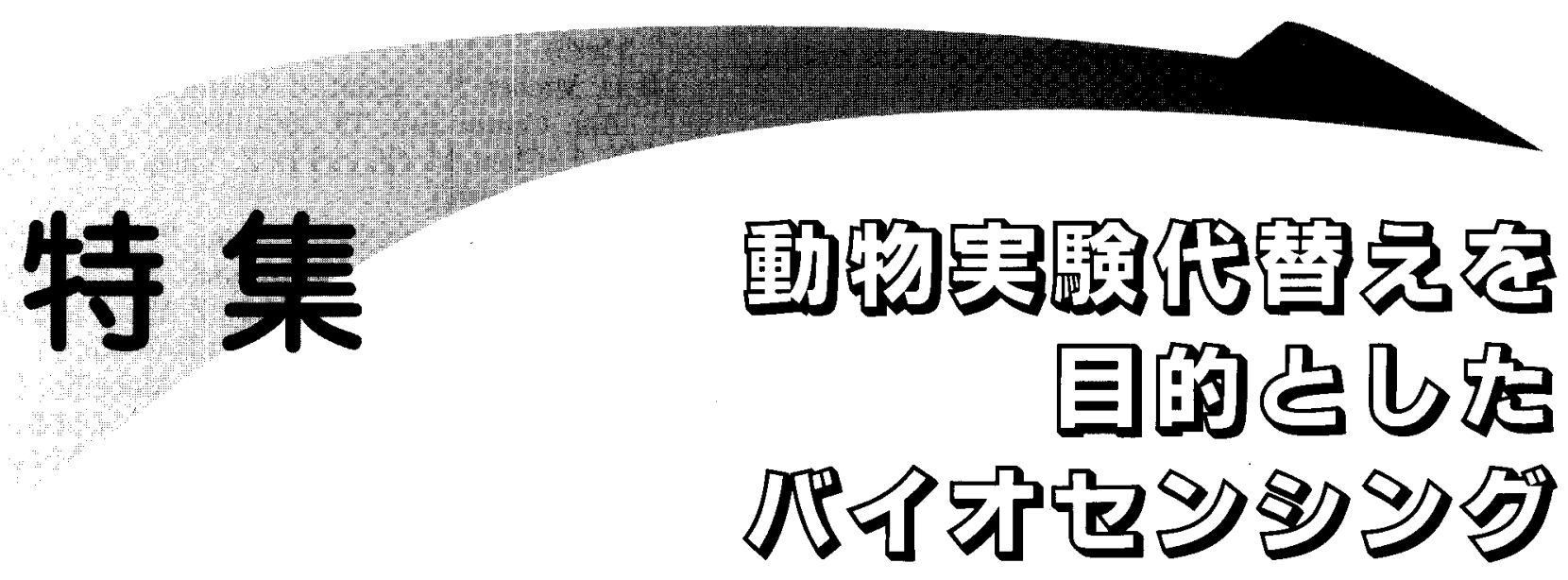

\title{
“動物実験代替えを目的としたバイオセンシング”を特集して
}

本特集では, 従来, 動物実験を用いて行われていた「薬剤スクリーニング」「安全性試験」「診断」などを 非動物実験系で行なうことを可能にするバイオセンシング技術に関する研究を展開しておられる4グループ に執筆をお願いした，動物実験は医薬開発をはじめ，安全性試験などにも必要不可欠であるが，動物保護の 観点から多くの制限が課せられる世界的趨勢がある。また，実験動物固体間の差異や実験の定量性などに関 する問題点も指摘されており，可能な範囲での動物実験代替え法開発が強く望まれるようになった。本特集 では, 鈴木先生による，「生物材料として醉母や真正粘菌を用いる毒性センサセンシングの試み」，春山らに よる「培養細胞系を用いた薬率スクリーニングシステムの開発」, 新井氏らによる「微生物の呼吸活性を指標 とした薬剤スクリーニング」など，医薬開発あるいは安全性試験の分野で動物実験代替え法となり得る研究 の成果に関して原稿を執筆していただいた．また，中村先生に執筆していただいた「アレルゲンセンサ」は， アレルゲン同定診断の分野で皮膚テストなど苦痛を伴う診断法の代替え法になり得るものとして本特集に加 えさせていただいた。ここで特集する研究はいずれも実験動物を必要としていた特定の実験系の代替え法と なり得る先駆的研究である。本特集が動物実験代替え法開発の萌芽となれば幸いである。

春山 哲也（東京工業大学: 生命理工学部)

\section{q アレルゲンセンサ}

\section{中村 徳幸}

\section{1 はじめに}

生体内には醉素, 抗体, 結合夕ンパク質など特定物質に対 する分子認識機能の優れた生体物質が存在する。なかでも抗 体は生体が外部からの異種タンパク，細菌，ウィルス，薬㣚 などの抗原の侵入に対し産生され，この抗原を排除し自己を 防衛する。これが, 免疫応答である.しかし，この免疫応答 は生体の防御以外に，ある条件のもとでは全身または局所に 障害を起こす場合がある。この異常な反応に基づく生体障害 作用がアレルギー反応，あるいは過敏症 (hypersensitivity) とよばれている，現在，アレルギーはCoombsと Gell によ ってI〜IVの4つの型に分類されている1). また, Roittによ ってV型が提唱されている゙. この中で, I 型アレルギ一反応
は血液中の好塩基球や組織中の肥満細胞の表面に存在するイ ムノグロブリン $\mathrm{E}(\mathrm{IgE})$ レセプターに $\mathrm{IgE}$ が結合し，この 抗体の抗原認識部位に対応する抗原（アレルゲン）が架橋的 に結合することにより，細胞での脱顆粒反応が起こる。この 脱顆粒反応により，ヒスタミン，七ロトニンやSRS-A (slow reacting substance of anaphylaxis）などのケミカルメデ イエーターが放出され, 気管支の収縮, 血管透過性立進, 腺 分泌の立進などが起こる、アレルギー性鼻炎, 花粉症, アト ピー性皮膚炎などのI 型アレルギー反応による疾患は近年, 徐々にその患者数も增加し, 現代病あるいは文明病と呼ばれ ている。

現在, アレルゲンの同定, $\operatorname{IgE}$ 抗体の検出・定量には皮䖉 
テスト(皮内，プリック，スクラッチ)，アレルゲン吸入誘発 試験，およびRAST (radioallergosorbent test)などが行 われている3,4)。しし，皮膚テストやアレルゲン吸入誘発試 験では患者がアナフィラキシーショックを起こす場合があり， またRASTでは放射性同位元素を用いるため, 操作が煩雑 なこと，高価であり，その処理に問題があるなどの欠点を有 する。このため, 新なな検出・定量法の開発が望まれている. 近年，不必要な動物実験やテストを排除しようという社会 的認識の高まりに伴い，種々の代替法の検討やその情報の提 供が CAAT (center for alternatives to animals testing, Johns Hopkins Univ.) やFRAME (fund for the replacement of animals in medical experiments）を始 め, 多くの研究機関で行われている。代替法(alternatives) は, 主に以下の 3 つの観点から研究が展開・開発されている.

（1）実験材料としての動物を他のものに置き換えること (replacement)

（2）実験方法を工夫して使用数を削減し，また実験期間の 短䌦化を図ること（reduction）

(3) 実験対象の苦痛を軽減すること, もしくは実騒技術の 改良により同心規模の実験から，より多くの情報を得る こと (refinement)

すなわち，あらゆる面から動物害験の効率的運用を四り， 可能な限り他のものに置き換えていこうとするものである.

このような観点を踏まえて, 筆者らのグループは, これま でに抗原抗体反応を利用した迅速・簡便なセンシングシステ ムの開発について進めてきた。本稿では，代替動物実娩を目 的とした電極型のアレルゲンセンサについて, 原理とその応 用ならびに，最近の研究動向を含めて紹介する.

\section{2 血球細胞を利用したアレルゲンセンサ}

抗体は抗原と結合すると, 種々の生物活性を示す。この活 性の一つに, 組織の細胞を刺激して抗原を排除する機能を始 動させる作用がある。抗体のこの作用に応答して，アレルゲ ンを排除する細胞の種類は多く，その主なものとしては血液 中に存在する顆粒球と単球, 組織中に存在するマクロファー ジと肥満細胞があげられる。

これまでに研究された電極型の免度センサの多くは, 電極 表面あるいは膜上に形成されな抗原抗体複合体による電極電 位もしくは膜電位の変動を测定することを原理として構成さ れている5.しかしながら，これらセンサの测定対象はホルモ ンの一種であるヒト絨毛性ゴナドトロピンや腫痬性抗原 $\alpha-$ フェトプロテインなどであり ${ }^{6)}$, 直接, アレルゲンを検出, 測 定できるセンサについては報告されていなかった。ここでは 血球細胞を利用したアレルギーセンサについて述べる。

\section{1 動物細胞を利用したアレルゲンセンサ}

アレルギー性鼻炎・喘息などの即時型（I 型）アレルギー は,アレルゲンに対して生体内で産生される IgE抗体が主な 原因と考えられている。好塩基球や肥満細胞は, 細胞表層に

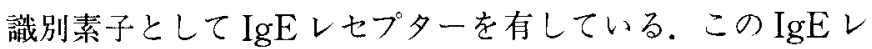
セプターに結合した $\operatorname{IgE}$ がアレルゲンで架橋されると, 細胞 内の塩基性顆粒やヒスタミン，七ロトニンなどの化学物質が 放出されてアレルギー反応が起こる．したがって，電極を利
用して細胞から放出される上記の物質を竍测することで，ア レルギー反応の検出も可能であると考え，Fig. 1に示した原 理により，動物細胞を用いたセンサシステムの構築を行った。 まず，IgEレセプターを有する RBL-1 (rat basophilic leukemia) 細胞をモデル細胞として使用した.この RBL-1 細胞 をメンブランフィルター上に吸着固定し，これを $\mathrm{BPG}$ (basalplane pyrolytic graphite) 電極に装着させ作用極と し, 対極には白金線, 参照極には飽和甘コウ電極（SCE： saturated calomel electrode）を用い，リン酸絠衝生理食 塩水 (PBS: pH 7.0) 中でサイクリックボルタメトリーを行 った (Fig. 2). その結果, $0.34 \sim 0.35 \mathrm{~V} と 0.68 \sim 0.70 \mathrm{~V}$ (vs. SCE 以後省略) 付近に特異的なピーク電流が得られた。 0.68 $\mathrm{V}$ 付近のピーク電流值と細胞内の補酵素A $(\mathrm{CoA})$ の間には 相関関係が得られ, CoA がこの電位における細胞一電極間の 電子移動反応の媒介物と推定された ${ }^{7)}$.もう一方の $0.34 \mathrm{~V}$ 付 近のピーク電流は, 細胞中に含まれるセロトニンが関与して いることが示された。そこで，マウス $\operatorname{IgE}($ 抗 DNP) で感作 した RBL-1 細胞にアレルゲンとしてジニトロフェニル化し た牛血清アルブミン（DNP-BSA）を加え，抗原抗体反心を 行わせた. $\operatorname{IgE}$ で感作させていない RBL-1 細胞の $0.34 \mathrm{~V}$ で のピーク電流值は $2.0 \times 10^{5}$ の細胞から $1.26 \mu \mathrm{A}$ であったの に対し， 2 時閒の抗原抗体反応により，脱顆粒が起きた細胞 のピーク電流值は $0.96 \mu \mathrm{A}$ に減少していた（Fig. 3).しか しながら, マウス IgE, DNP-BSA のみを加えた場合ではピ 一ク電流值に変化はみられなかった，液体クロマトグラフィ

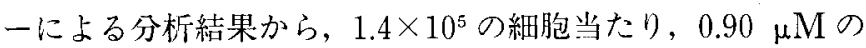
七ロトニンの細胞外への放出が確認された。ささに，他のア レルゲン（卵白，ミルク，花粉など）の抽出液を加えた場合

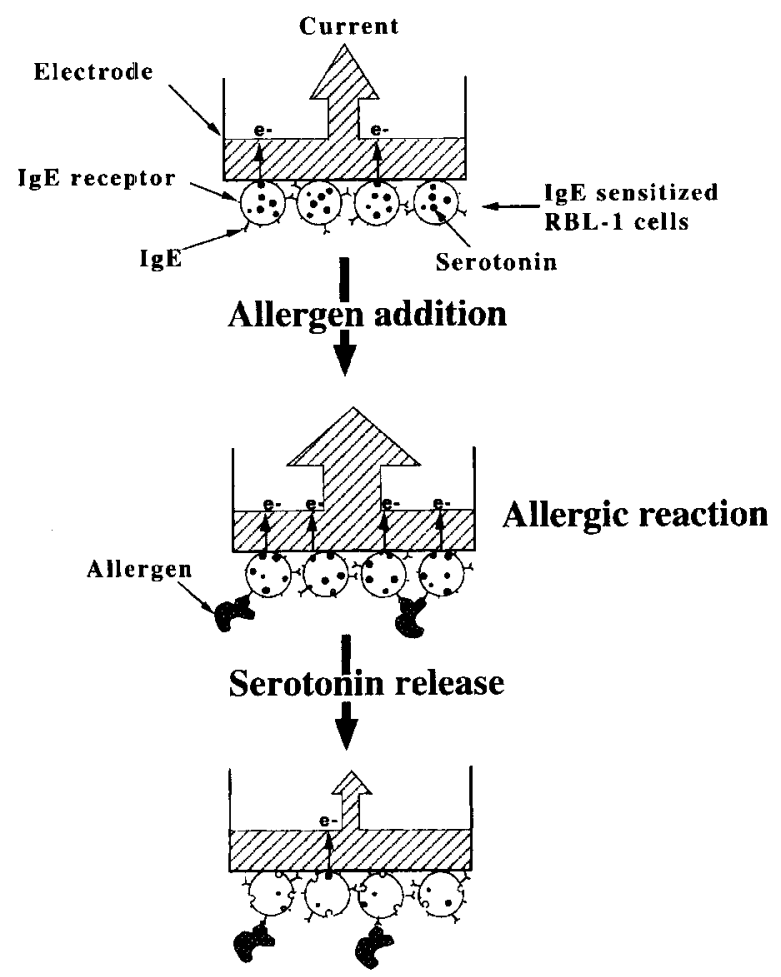

Fig. 1 Schematic diagram showing mechanism of allergen detection by cyclic voltammetry. 


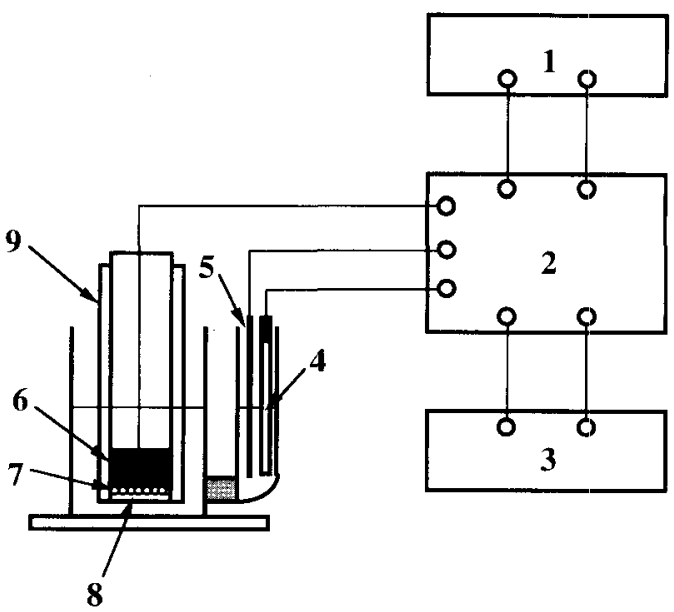

Fig. 2 Schematic diagram of the electrode system for allergen detection using animal cells.

$1:$ Function generator, $2:$ Potentiostat, $3: \mathrm{X}-\mathrm{Y}$ recorder, 4 : Reference electrode (SCE), 5 : Counter electrode (platinum wire), 6 : Working electrode (BPG), $7:$ Cells, $8:$ Membrane filter, 9 : Holder.

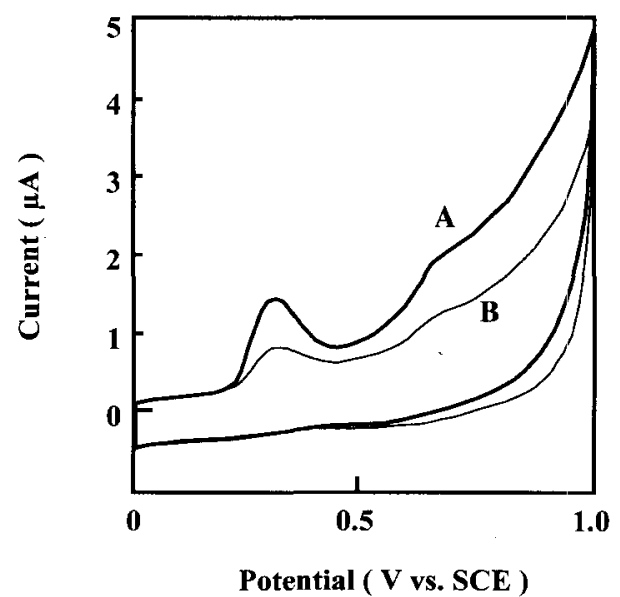

Fig. 3 Cyclic voltammograms of IgE sensitized RBL-1 cells before (A) and after (B) $2 \mathrm{~h}$ of incubation with allergen. Scan rate $: 20 \mathrm{mV} / \mathrm{s}$

では，ピーク電流值の減少はみられず，セロトニンの放出も

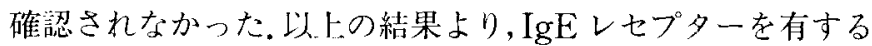
細胞とアレルゲンの 2 時間の反応で, その $\operatorname{IgE} に$ 对応したア レルゲンを電極のピーク電流值の減少量によって検出できる ことが明らかになった.しかも, ピーク電流值の減少量は細胞 から放出されるセロトニンの量と相関関係があり，これを指 標にアレルギー反応の度合も推定できることが示唆された8). また，小麦アレルギーのラットより血清を採取して調製し た小麦抗体を用いて RBL-1 細胞を感作させ，食物タンパク 質に対する応答について調べた。感作させた RBL-1 細胞に 小麦のタンパク質を加え，インキュベーションした後，サイ クリックボルタンメトリーを行ったところ，七ロトニンに由

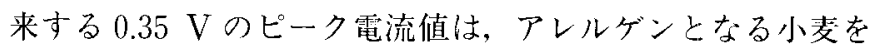
添加直後では $4.0 \times 10^{5}$ 細胞当たり $0.02 \mu \mathrm{A}$ であったのに対し， インキュベーションの時間とともに電流值は増大し，アレル
ゲン添加 25 分後に最大 $0.50 \mu \mathrm{A}$ となり，その後徐々に減少し た (Fig. 4)。また，アレルゲンを添加せずにインキュべート

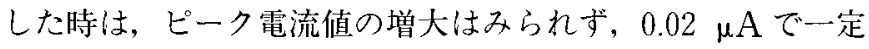
であった。これは, 細胞内顆粒がある時間までは細胞内で蓄 積され，後に細胞外に放出されるという，アレルギ一反応に みられる脱顆粒反応の過程をモニタリングしているものと推 測された。

一方，小麦タンパク質濃度に対するピーク電流值を調べた ところ, 濃度の増加とともにピーク電流值は増大し $0.01 \sim 0.5$ $\mu \mathrm{g} / \mathrm{ml}$ の範囲では良好な相関関係が得られ，1 $\mu \mathrm{g} / \mathrm{ml}$ 以 上ではピーク電流值は一定になった (Fig. 5)。このシステム による検出限界は $0.01 \mu \mathrm{g} / \mathrm{ml}$ であり, 他の大豆や牛乳, 卵 のタンパク質を加えてもピーク電流值は変化しないことから

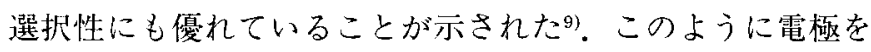
用いることで, 食物中に含まれるアレルゲンを 30 分以内で検 出可能となり, しかも従来の皮膚テスト等に比べてより高感 度な検出に適用可能なことが示された。

\section{2 白血球を利用したアレルゲンセンサ}

白血球には顆粒球，リンパ球，単球などが含まれ，免疫反 応に関与することが知られている. 前項で取りあげた RBL-1 細胞はラット由来のものであり，継代培養を行わなければな らないといった，実際のヒトに対するアレルゲンの検出の際 に不利な点があった。 そこで，ヒトの血液より白血球を分離 し，識別素子としてセンサへ利用した。

採血後, 血液に $2 \%$ チルセルロース溶液を添加し, 赤血 球を沈降させ，上清中に含まれる白血球を遠心により分離し， それぞれの電極反応について調べた。まず，サイクリックボ ルタンメトリーを行ったところ, 赤血球では 0.67〜0.70 V で $0.87 \mu \mathrm{A} / 10^{6}$ cellsのピーク電流值が得られたが, 白血球 $\left(10^{6}\right.$ cells) では $0.30 \sim 0.34 \mathrm{~V}$ と $0.65 \sim 0.67 \mathrm{~V} て ゙ 0.65 \mu \mathrm{A}$ と $0.25 \mu \mathrm{A}$ のピーク電流值がそれぞれ得られた. また, 白血 球を超音波処理し，その上清のサイクリックボルタンメトリ 一を行ったところ, $0.29 \mathrm{~V}$ でピーク電流值が得られた.これ

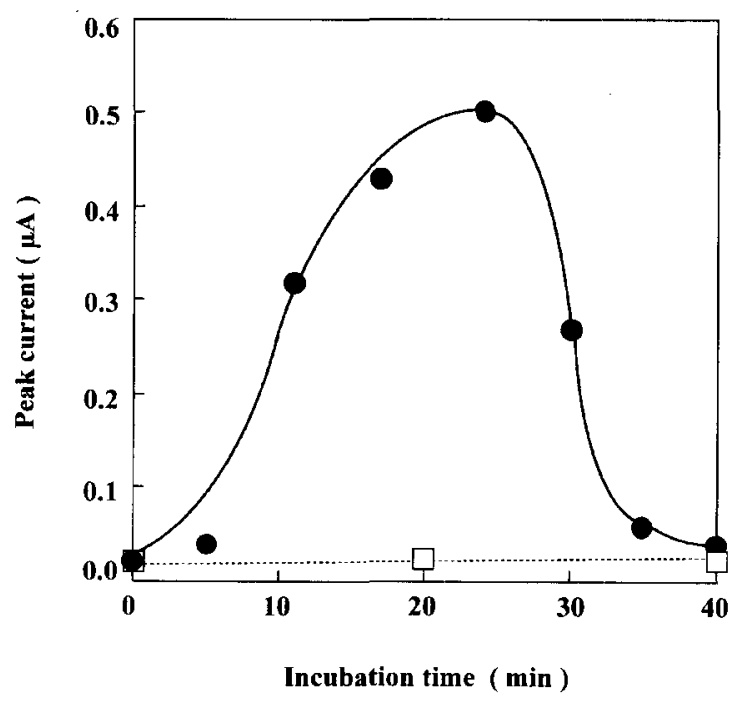

Fig. 4 Relationship between incubation time and peak current of sensitized RBL-1 cells with $(\mathbf{O})$ and without $(\square)$ allergen. 


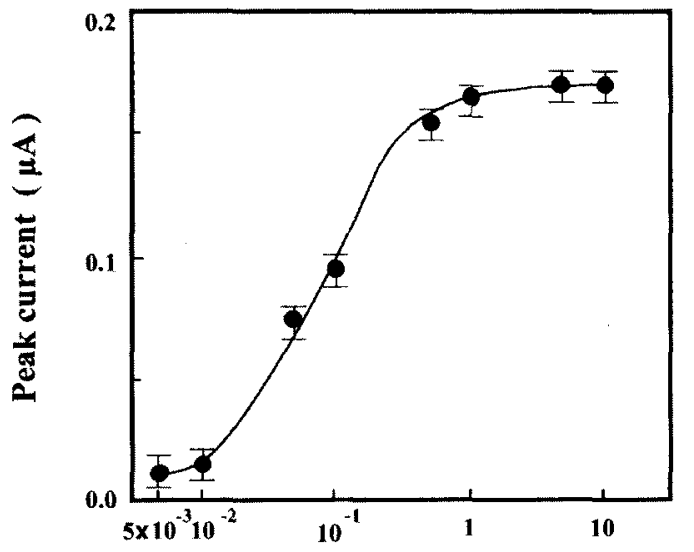

Protein concentration $(\mu \mathrm{g} / \mathrm{ml})$

Fig. 5 Relationship between wheat protein concentration and peak current of sensitized RBL-1 cells.

はセロトニン溶液のみのビーク電位とほぼ一致していた。こ れより，白血球においても RBL-1 細胞と同様にセロトニン が電極反応していることが示された，そこで，卵のアレルギ 一患者から得られた白血球にアレルゲンとして即白を加えた 後, サイクリックボルタンメトリーを行ったところ, $0.33 \mathrm{~V}$ 付 近のピーク電流值が $0.27 \mu \mathrm{A} / 10^{6}$ cells から $0.19 \mu \mathrm{A} / 10^{6}$ cells に減少した。 これは, 白血球中のセロトニンが脱顆粒に より放出されたためと推察された.さらに，放出されるセロ トニンを蛍光分光光度計で測定したところ，何も加えていな いときのセロトニンの放出量が $0.06 \mathrm{nmol} / 5.0 \times 10^{5}$ cellsで あったのに対し, 卵白の抽出液を $10 \mu \mathrm{g} / \mathrm{ml}$ 加えたときには $0.34 \mathrm{nmol} / 5.0 \times 10^{5}$ cells となった.アレルゲンの濃度を增 加させていくと，50 $\mu \mathrm{g} / \mathrm{ml}$ で放出量が $0.42 \mathrm{nmol} / 5.0 \times 10^{5}$ cells となり，この濃度以上ではセロトニンの放出量は，ほと んど変化しなくなった．また，アレルゲンの濃度を $10 \mu \mathrm{g} / \mathrm{ml}$ として大豆，牛乳で同様な実騩を行いセロトニンの放出を測 定したところ，大豆では $0.16 \mathrm{nmol} / 5.0 \times 10^{5}$ cells, 牛乳で は $0.10 \mathrm{nmol} / 5.0 \times 10^{5}$ cells 放出されたが，㽗白に比べセ ロトニンはあまり放出されなかった。この結果から, 卵のア レルギー患者から得られた白血球は卵白にのみ特異的に反応 し, 脱顆粒によりセロトニンが放出されたことが明らかにな つた，また，七ロトニンの放出量からアレルゲンを検出する ことができ，ヒトに対するアレルギ一反応を白血球を用いて 直接测定できることが示された ${ }^{10)}$.

\section{3 マイクロ電極を用いたアレルゲンセンサ}

動物細胞や白血球を用いた手法は, 培養が必要なことや分 離操作が煩雑であるといった問題点を有していた，各個人が 何に対してアレルギーなのか, 寸なわち何がその人のアレル ゲンとなりうるのかを容易に知ることも重要である。そこで, マイクロ電極と全血を利用したアレルゲンセンサについて， そのシステムを作製し，アレルゲンに関する自己診断への適 用の可能性について検討した。電極には沛販の微小クシ型電 極を用い，微小電極用ポテンショスタット拈よびレコーダー からなるシステムを作製した。 サンプルとなる血液は，血糖
值測定用キットの中にあるディスポタイプの剥刺を用いて， 指先から $20 \mu \mathrm{l}$ を採取した。凝血防止のためへパリンで処理 したマイクロチューブに滴下し，抗 IgE 抗体や市販のスギ花 粉, 卵やエビのアレルゲン溶液を添加，インキュベートし， 電流を測定した。

まず，マイクロ電極を用いて報告されているセロトニンの 電極反応についてサイクリックボルタンメトリーを用いて検 討した。その結果，これまでと同様に $0.35 \mathrm{~V}$ 付近にセロトニ ン由来のピーク電流が確認された。 そこで，全血にセロトニ ンを加え, $0.35 \mathrm{~V}$ の定電位で測定を行った結果, セロトニン の濃度が50 - 800 $\mathrm{ng} / \mathrm{ml}$ の範国では得られた電流值の間 に良好な相関関係が示された (Fig. 6)。血液中のセロトニン 含量は $120 \pm 10 \mathrm{ng} / \mathrm{ml}$ であることから，マイクロ電極によ る全血を用いたアレルギ一反応に基づくアレルゲンの検出が 可能であることが示唆された。, 次に, 全血に抗 IgE抗体を加 えアレルギー反応を誘発させ，脱顆粒反応により放出される セロトニンの释時変化を調べた。抗 $\operatorname{IgE}$ 抗体を全血に添加

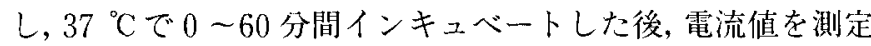
したところ, 添加後 20 分から值の増加がみられ, 40 分後に最 大に達し，以降は徐々に減少しな。対照として緩衝液を添加 して同様の実験を行った場合には，電流値の増加はみられな かった.このことから，抗体添加 20 分以降の電流值の増加は アレルギー反応により，血液中に存在するセロトニンが電極 で反笖したもので，40 分以降は時閒とともに活性が失われた ものと考えられた，対照害験との比較で，電流值の差は添加 後 40 分に最大となったことからここの時の電流值で実際のア レルゲンの検出に適用文ることにした，スギ花粉症の患者の 全血にスギ花粉，卵及びエビのアレルゲンを添加し，0.35 V の定電位での電流值の測䇥を行い比較した，その結果，スギ 花粉のアレルゲンを添加した全血から得られた電流值は27.1 nAであったのに対し，眀，エビのアレルゲンを添加した場合

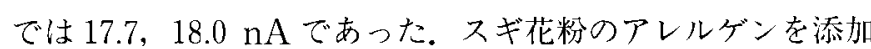
することにより, 電流值が約 10 nA 増加していることが示さ れた (Table 1)。 スギ花粉の添加による電流做の増加はアレ ルギー反応によって生じたものと考えることができ，この検 出システムの測定における選択性が優れていることが示唆さ

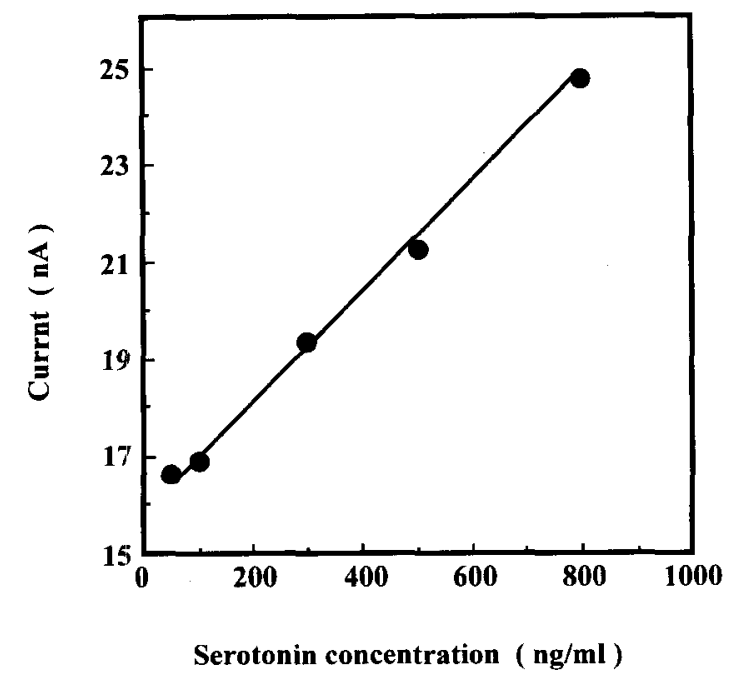

Fig. 6 Calibration curve for serotonin concentration. 
れた ${ }^{11)}$. 以上のことから, $20 \mu \mathrm{l}$ という微量な全血とマイクロ 電極を用いたアレルギーセンサにより，アレルゲンの自己診 断への適用可能なシステムが構築できた。

\section{4 おわりに}

以上, 電気化学的なアレルゲンセンサについて, その原理 や応用について述べてきた. 今後, デバイスの改良や開発に 上り，高感度化，高選択性などの特性を持つセンサが作製さ れ，その応用も広がるものと考えられる。すでに電極以外に， 光ファイバーと抗体固定化膜を組み合わせたアレルギーセン サ ${ }^{12)}$ や磁気微粒子を抗体固定化担体として $\operatorname{IgG}^{13)}$ や微生 物 ${ }^{14)}$ の検出に適用した例もある。また，抗原抗体反心により 形成された複合体の分子量や等電点の差からイオン交換力ラ ムと発光基質 ${ }^{15)}$ や蛍光色素 ${ }^{16)}$ によるアレルゲンの検出も行 われている.さらには, 膠原病患者の血清中の抗 ds DNA 抗 体の検出への適用が報告されている ${ }^{17)}$. 今後の進展により抗 原抗体反応のメリットを生かした花粉症，アトピ一性皮膚炎 などのアレルギー反応の診断や，アレルゲンの検出などへの 展開が期待される。

\section{文 献}

1) R. R. A. Coombs and P. G. H. Gell, Clinical Aspects of Immunology, 3rd edition, Blackwell Scientific Publishing (1975).

Table 1 Currents of whole blood obtained from a positive person with a cedar allergy when various allergens were added.

\begin{tabular}{cc}
\hline Allergen & Current $(\mathrm{nA})$ \\
\hline Cedar & 27.1 \\
Egg & 17.7 \\
Prawn & 18.0 \\
Control & 17.7 \\
\hline
\end{tabular}

Allergen concentration was adjusted to $100 \mu \mathrm{g} / \mathrm{ml}$. Currents were measured after 40 min of incubation with allergen.
2) I. M. Roitt, Essential Immunology, Blackwell Scientific Publishing (1975)

3) 畔柳武雄, 大橋裕一, 松橋 值, 新免疫学業書 7, 免伇とアレ ルギー，医学書院 (1981)。

4) Y. Green-Graif and P. W. Ewan, Clin. Allergy, 17, 431 (1987).

5) N. Yamamoto, Y. Nagasawa, S. Shuto, H. Tsubomura, M. Sawai, and H. Okumura, Clin. Chem., 26, 1569 (1980).

6) M. Aizawa, A. Morioka, S. Suzuki, and Y. Nagamura, Anal. Biochem., 94, 22 (1979).

7) T. Matsunaga and Y. Namba, Anal. Chem., 56, 798 (1984).

8) T. Matsunaga, A. Shigematsu, and N. Nakamura, Anal. Chem., 61, 2471 (1989).

9) N. Nakamura, S. Kumazawa, and T. Matsunaga, Appl. Microbiol. Biotechnol., 43, 622 (1995).

10) N. Nakamura, I. Inoue, Y. Kitajima, T. Matsunaga, T. Chiba, and T. Honda, Biosensors Bioelectr., 6, 431 (1991).

11) T. Matsunaga, H. Yokouchi, M. Okochi, and N. Nakamura, Abstr. 4th World Congress on Biosensors, p. 285 (1996).

12) N. Nakamura and T. Matsunaga, Anal. Lett., 24, 1075 (1991).

13) T. Matsunaga, M. Kawasaki, X. Yu, N. Tsujimura, and N. Nakamura, Anal. Chem., 68, 3551 (1996).

14) N. Nakamura, J. G. Burgess, K. Yagiuda, S. Kudo, T. Sakaguchi, and T. Matsunaga, Anal. Chem., 65, 2036 (1993).

15) T. -K. Lim, N. Nakamura, and T. Matsunaga, Denki Kagaku (presently Electrochemistry), 63, 1154 (1995).

16) T. -K. Lim, N. Nakamura, and T. Matsunaga, Anal. Chim. Acta, 354, 29 (1997).

17) T. -K. Lim, Y. Komoda, N. Nakamura, and T. Matsunaga, Anal. Chem., (1999), in press.

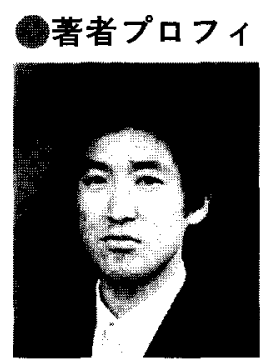

氏名：中村 徳幸 Noriyuki NAKAMURA 所属：通商産業省工業技術院 産業技術融合 領域研究所（干305-8562つくば市東 $1-1-4)$

役職：主任研究官

趣味：スポーツ(サッカー，スキー)，ドライ ブを兼㱛な温泉・名水巡り

\section{図書紹介}

\section{$\mathrm{X}$ 線分析の進歩 30}

編集/日本分析化学会，X 線分析研究愁談会，発行/橉アグネ技術センター（1999），定価5,500 円

\section{I 特別笴稿}

1. X 線分析法の進展と X 線分析研究想談会の発展を顧みて II 報文

2. Ti 酸化膜の波長分散型蛍光 X 線スペクトル測定

3. 簡易型二結晶分光器によるX 線輻射スペクトル

4. $\mathrm{Cu}$ の $\mathrm{K}$ 系列 X 線輻射スペクトルの微細構造

5. カーボン材料の放射光励起高分解能軟 X 線発光・吸収 スペクトル

6.散乱と重なりを考慮した蛍光 X 線強度の理論計算, 及 び定量分析への応用
ほか

III技術報告

20。型放射光源を用いた全反射蛍光 $X$ 線分析 IVノート

21. 水溶液試料のポリイミドフィルム点滴による微量金属 EDS 分析

$\mathrm{V}$ 。既掲載 X 線粉末回折図形索引

VI. 1998 年 X 線分析のあゆみ

VII. X 線分析関連機器資料

ほか 